V. V. GORBUNTSOV, O. M. ZAVOLOKA, A. P. KREMENA, M. F. SVYRYDENKO

\title{
SIMULATION OF THE EVOLUTION OF A DROPLET CLOUD THROWN INTO THE ATMOSPHERE AS A RESULT OF AN EXPLOSION OF A LAUNCH VEHI- CLE WITH SELF-INFLAMMABLE PROPELLANT COMPONENTS
}

\author{
Institute of Technical Mechanics \\ of the National Academy of Sciences of Ukraine and the State Space Agency of Ukraine \\ 15 Leshko-Popel St., Dnipro 49005, Ukraine; e-mail: office.itm@nas.gov.ua
}

\begin{abstract}
The aim of this work is to develop a methodological approach to simulating the evolution of a droplet cloud (DC) formed as a result of an explosion of a launch vehicle with self-inflammable propellant components in the initial portion of the flight trajectory and thrown into the atmosphere with initial motion parameters that correspond to the launch vehicle position at the time of the explosion. The proposed approach, which is based on a phenomenological analogy with the motion of a fuel spray injected in the combustion chamber of a diesel, takes into account the fragmentation and tracing of droplets and the effect of their collisions and possible coalescence on the structure and parameters of the propellant component DC, which undergoes a transformation as it moves. The proposed model of the DC evolution, which is due to droplet interaction in the DC and its structuring in the process of motion, reflects the most important, in terms of the environmental consequences of the explosion, processes in the DC and allows one to estimate its basic kinematic and geometric characteristics required for solving the ballistic problem of the motion of the suspended DC droplets in the atmosphere and their precipitation onto the ground surface.
\end{abstract}

Keywords explosion, droplet cloud, droplet, propellant component, launch vehicle.

1. Pylypenko O. V., Gorbuntsov V. V., Zavoloka A. N., Sviridenko N. F. Determination of initial characteristics of fuel components droplet cloud derived from in-flight explosion of carrier rocket (in Russian). Tekhnicheskaya Mekhanika. 2017. No. 1. Pp. 3 - 14.

2. Demirchan K. S., Kondratiev K. E., Dabilevich Ya. B.,Demirchan K. K. IPCC scenarios of dangerous climate changes are based on realistic premises (in Russian). Izvestiya RAN. Energetika. 2003. No. 4. Pp. 89-121.

3. Arkhipov V. A., Zharova I. K.,Kozlov .I., Ykachenko A. S. Applied ecological aspects of the aerospace hardware operation (in Russian). Optika Atmosfery i Okeana. 2013. V. 26. No. 8. Pp. 636 - 641.

4. Surzhikov S. T. Prediction and analysis of extreme exposure factors (in Russian): Materials and Coatings in Extreme Conditions. A Glance into the Future: in 3 volumes. V. 1 : S. V. Reznik (Ed.). Moscow: Bauman Moscow State Technical University, 2002. Pp. $157-172$.

5. Stebnovsky S. V., Cheryutaev N. N. Effect of the loading dynamics of a liquid cloud on the mechanism of its destruction (in Russian). Prikladnaya Mekhanika i Tekhnicheskaya Fizika. 1987. No. 5. Pp. 134 - 139.

6. Ponomarenko V. K. Rocket Propellants (in Russian). St. Petersburg: Mozhaysky Red Banner Order Military Space Engineering Academy, 1995. 619 pp.

7. Lavrentiev M. A., Shabat B. V. Hydrodynamics Problems and their Mathematical Models (in Russian). Moscow: Nauka, 1973. 416 pp.

8. Explosion Physics : L. P. Orlenko (Ed.) : in 2 volumes. V 2. Moscow: Nauka, 2004. 656 pp.

9. Gelfand B. E., Gubin S. A., Kogarko S. M. Diversity of droplet fragmentation in shock waves and dropet characteristics (in Russian). Inzhenerno-Fizicheskii Zhurnal. 1974. V. 27. No. 1. Pp. $119-126$.

10. Kovalenko O. V. Dynamic Destruction and Dispersion of Condensed Media (in Russian). Ph.D. thesis synopsis. March 5, 2016. Moscow: Moscow Engineering Physics Institute, 1991. 20 pp.

11. Arkhipov V. A., Berezinov A. P., Tkachenko A. S., Usanina A.S. Generalized model of the propagation of liquid-droplet cloud formed as a result of fuel dumping (in Russian). Izvestiya Vysshikh Uchebnykh Zavedenii. Fizika. 2010. No. 12 (2). Pp. 10 - 13.

12. Sviridov Yu. B., Malyavsky L. V., Vikhert M. M. Fuel and Fuel Supply of Automotive Engines (in Russian) Leningrad: Mashinostroyeniye, 1979. 248 pp.

13. Melnikov A. P. Brief Course in Aerodynamics (in Russian). Leningrad: Leningrad Red Banner Order Air Force Engineering Academy, 1949. $261 \mathrm{pp}$

14. Abramovich G. N. Turbulent Jet Theory (in Russian). Moscow: Nauka, 1984. 400 pp.

15. Babukha G. L., Shraiber A. A. Effect of polydisperse particle collisions on the motion and interphase heat exchange in a vertical two-phase flow (in Russian). Prikladnaya Mekhanika i Tekhnicheskaya Fizika. 1966. No. 4. Pp. $23-29$.

16. Kinelovsky S. A., Trishin Yu. A. Physical aspects of cumulation (in Russian). Fizika Goreniya i Vzryva. 1980 No. 5. Pp. $26-40$.

17. Kuznetsov A. A. Efficiency Optimization of Ballistic Rocket Parameters. Moscow: Mashinostroyeniye, 1986. $160 \mathrm{pp}$. 